\title{
鼻咽頭チューブ10例の使用経験
}

\author{
中島千賀子, 横山 美貴, 宮川 知士 \\ 土屋 康子, 雉本 忠市
}

(国立小児病院呼吸器科)

\begin{abstract}
要旨：鼻咽頭チューブは, Pierre-Robin 症候群や重度心身障害児などの上気道閉塞の管理に広く用 いられている。今回私達は昭和 60 年 1 月から平成 6 年 1 月に当科で鼻咽頭チューブ管理を開始した 10例について検討した。

開始年齢は 1 力月から 9 歳 5 力月, 中央値は 6 力月であった。上気道閉塞の原因は, 小顎症 3 例 (うち 1 例は Pierre-Robin 症候群), 軟骨異栄養症 2 例, 口蓋裂術後鼻咽腔狭窄, 先天性鼻道狭窄, 睡眠時無呼吸, 扁桃肥大, 上咽頭狭窄がそれぞれ 1 例であった。10例のうち，8例は有効で, 右室 肥大, 肺性心も改善された。無効であった 2 例は, それぞれ中枢性無呼吸, 気管気管支軟化症を合 併していた。チューブによる重大な合併症を認めず， 5 力月から 4 年 8 力月，平均 2 年 4 力月間使 用している。

鼻咽頭チューブは, 種々の上気道閉塞に対し有効で簡便な治療法であり, 患児つ quality of lifeの 向上につながると考える。
\end{abstract}

\section{Nasopharyngeal Airway Management; Summary of Our 10 Cases}

\author{
C. Nakajima, Y. Yokoyama, T. Miyakawa, \\ Y. Tsuchiya, C. Kijimoto \\ Department of Pulmonology, National Children's Hospital, Tokyo, Japan
}

Nasopharyngeal airway has been used as the treatment of upper airway obstruction in children. We studied the ten cases who received nasopharyngeal airway management in our hospital from Jan. 1985 to Jan. 1994.

They were begun the nasopharyngeal airway management at the age from one month to 9 -year-5-month-old (median $=6$ months). The causes of the upper airway obstructions were three microgenias, including one Pierre Robin syndrome, two dyschondroplasias, nasopharyngeal stenosis following operation of cleft palate, congenital nasal stenosis, obstructive sleep apnea, and so on. Eight of ten were effective, two of eight also improved the right ventricular hypertrophy and cor pulmonale. The last two were not effective because both of them had complications : central apnea and tracheobronchomalasia respectively. The durations of nasopharyngeal airway management were from 5 months to 4 years and 8 months (mean $=2$ years and 4 months). No severe complication was seen.

We conclude nasopharyngeal airway management is effective and convenient treatment for upper airway obstructions caused by many kinds of diseases. It might improve the quality of life of these children.

Key words : 鼻咽頭チューブ, 上気道閉塞 


\section{1.はじめに}

鼻咽頭チューブは Pierre-Robin 症候群など の小顎症に伴う上気道閉塞や，重度心身障害児 の舌根沈下などによる閉塞性無呼吸の治療法と して広く用いられている ${ }^{1,2)}$ 。その応用範囲と有 用性を明らかにするため，昭和60年 1 月から平 成 6 年 1 月に当科で鼻咽頭チューブ管理を開始 した10例について検討した。

\section{2. 対象と方法}

対象は昭和 60 年 1 月から平成 6 年 1 月に当科 で鼻咽頭チューブ管理を開始した10例（男児 8 例, 女览 2 例)。開始年歯は生後 1 力月から 9 歳 5 力月。中央值は 6 力月で， $60 \%$ が 1 歳未満。 上気道閉塞の主な原因は小顎症 3 例, 軟骨異栄 養症 2 例, 以下口蓋裂術後硬口蓋短縮, 先天性 鼻道狭窄，睡眠時無呼吸，扁桃肥大，上咽頭狭 窄がそれぞれ 1 例である(表 1 )。小顎症 3 例の うち 1 例は Pierre-Robin 症候群と軟口蓋裂を 合併し，1 例は Poland 奇形と脳性麻痺, 残りの 1 例は大動脈狭窄とアデノイドを合併してい
た。睡眠時無呼吸の症例は腰仙部脊髄髄膜瘤を 合併し, Arnold-Chiali 症候群が疑われている。 扁桃肥大の症例は重度の精神発達遅滞があり手 術が見送られていた。

また，右室肥大や肺性心を合併する重度の閉 塞は 2 例であった。

鼻咽頭チューブの管理方法は, まず Portex の気管内捙管チューブを鼻孔より挿入し，チュ ーブの先端が舌根の直下，喉頭より上になるよ うに，透視下または喉頭ファイバースコピーで 位置を確認する(図 1)。チューブ遠位端の鼻孔 の位置に安全ピンを刺し, 安全ピンの両端に付

表 1 上気道閉塞の原因

\begin{tabular}{|l|l|}
\hline 小顎症* & 3 \\
\hline 軟骨異栄養症 & 2 \\
\hline 口蓋裂術後 & 1 \\
\hline 先天性鼻道狭窄 & 1 \\
\hline 睡眠時無呼吸 & 1 \\
\hline 扁桃肥大 & 1 \\
\hline 上咽頭狭窄 & 1 \\
\hline
\end{tabular}

*Pierre-Robin症候群1例を含む
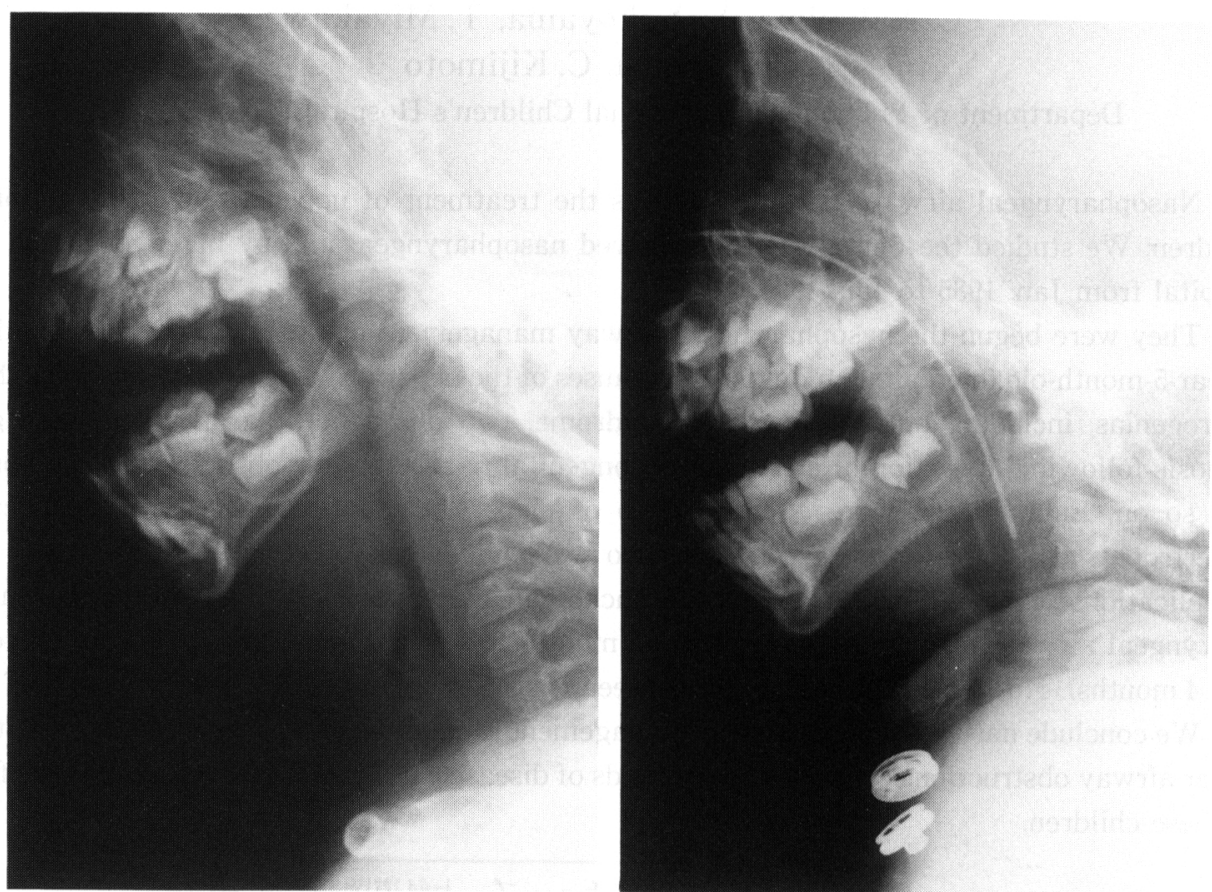

図 1 頸部側面レントゲン写真 左：チューブ扱入前，右：チューブ扱入後 
けた系を両煩部にテープで固定する。チューブ 先端から鼻孔までのチューブの長さを，チュー ブの深さとした。チューブのサイズと深さを決 定し，家庭では 1 週間に 1 回家族が交換してい る。夜間に限り使用している 5 例は, 就寝前に 家族が捚入し, 昼間は消毒液内に保管している。

この10例についてチューブの内径と深さ，使 用期間，合併症や栄養方法を検討し，睡眠時酸 素飽和度モニタリング（以下， $\mathrm{Spo}_{2}$ study）及 び心電図, 心エコーなどから治療効果を判定し た。

統計学的処理は, 治療前後の $\mathrm{Spo}_{2}$ study の比 較に, paired $\mathrm{t}$ 検定を行った。

\section{3 . 結果}

\section{a .チューブの内径と深さ}

鼻腔狭窄の 1 例を除いて，チューブの内径は 乳幼览では $3.5 \mathrm{~mm}$, 年長児では $4.5 \mathrm{~mm}$ であっ た。体重との相関を認めなかった $(r=0.675)$ (図 2 )。

チューブの深さは $6.0 \mathrm{~cm}$ から $10.0 \mathrm{~cm}$ で体 重と正の相関を認めた（ $\mathrm{r}=0.871 ）$ (図 3$)$ 。

b. 治療効果

10 症例中 8 症例は閉塞性無呼吸および $\mathrm{Spo}_{2}$ の改善を認め,このうちを $\mathrm{Spo}_{2}$ study を行った 6 例のチューブ指入前後の平均 $\mathrm{Spo}_{2}$ の変化を 図 4 に示す。挿入前は 88 から $92.8 \%$, 平均 $90.3 \pm$ $0.660 \%$, 挿入後は 95 から $99.9 \%$, 平均 $97.3 \pm$ $0.795 \%$ と改善し, 有意水準 $5 \%$ としたとき $\mathrm{p}=$ 0.0002で有意差を認めた。

また，右室肥大や肺性心をきたした重度な閉 塞例は 2 例とも, 呼吸状態の改善に伴い右室肥 大や肺性心が改善した。すなわち, 先天性鼻道 狭窄の 1 例は心電図所見から右室肥大，心エコ 一から軽度の右心系拡大を認めたが鼻咽頭チュ ーブ治療開始後速やかに改善した。軟骨異栄養 症の 1 例は, 全身浮腫, 胸部レントゲン上心胸 郭比 $70 \%$, 心電図, 心エコーから右房拡大, 右 室肥大を認め, 肺性心を生じていた。鼻咽頭チ ューブ治療開始後 1 週間で心電図上は右室肥大 が残るものの, 呼吸困難の軽減, 浮腫の消失, 心胸郭比 $60 \%$ ，心エコー所見の著明な改善を認 めた。

しかし Pierre-Robin 症候群の 1 例では $\mathrm{Spo}_{2}$
は改善したものの，分泌物が多く口腔内持続吸 引を行っていたが，1 カ月後には腹臥位で管理 可能となったためチューブを抜去している。

呼吸状態の改善しなかった 2 例のうち 1 例は 腰仙部脊䯣髄膜瘤で中枢性無呼吸も加わってい ると考え，低濃度酸素を投与したところ $\mathrm{Spo}_{2}$

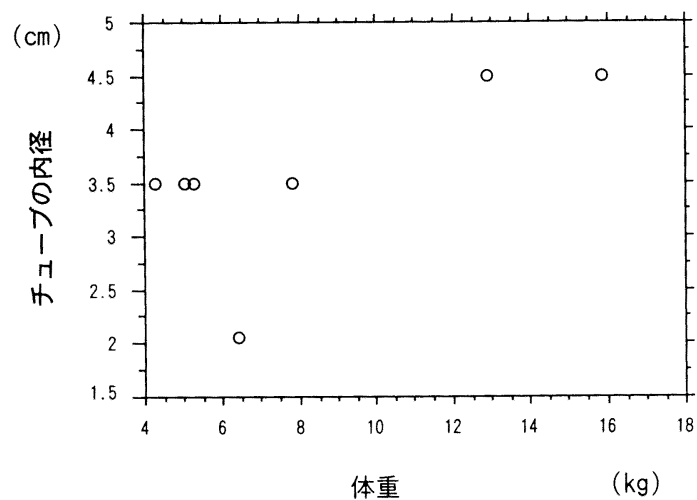

図２チューブの内径と体重

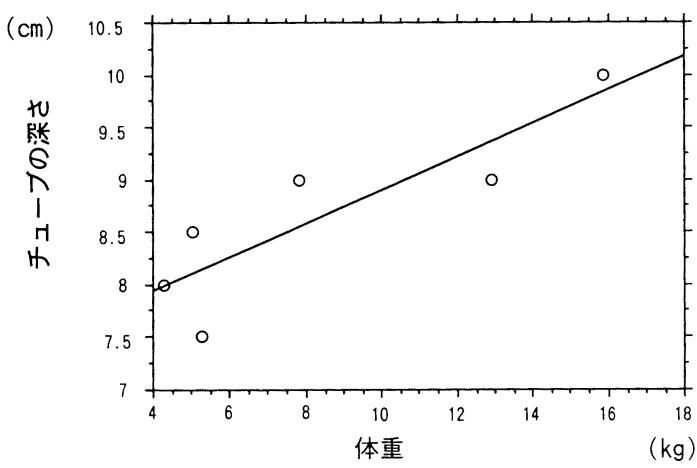

図３チューブの深さと体重

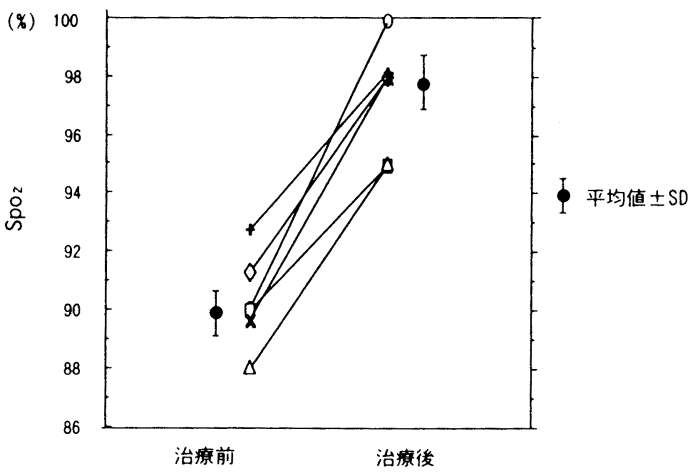

図 4 睡眠時平均 $\mathrm{Spo}_{2}$ の変化 
は改善した。また，もう 1 例は鼻咽頭チューブ が無効であったため，無管支ファイバー，気管 支造影検查を行い喉頭気管気管支軟化症と診断 し気管切開を行った。

\section{c . 使用期間}

鼻咽頭チューブの使用期間は 5 カ月から 4 年 8 力月, 平均 2 年 4 力月であった。

観察期間中に上気道閉塞が改善し鼻咽頭チュ ーブを抜去できたものは 2 例で，それぞれ 5 力 月間と 9 力月間で抜去している。原疾患は先天 性鼻道狭窄と小顎症であった。他の 2 例も臨床 上は改善し, $\mathrm{Spo}_{2}$ studyもほぼ正常化し,チュー ブ抜去を試みているが，上気道感染を機に呼吸 状態が悪化し, 結局チューブ管理を続けている。

d . 合併症

鼻腔口腔内の分泌物が増加したが，重篤なも のは認めなかった。

\section{e. 栄養方法}

鼻咽頭チューブ管理中の栄養方法は，3 例は 小䫵症による哺乳困難や嚥下障害のため経管栄 養を受けている。経口掑取が可能でも嚥下時に チューブから食物が逆流してしまう場合には食 事の時だけチューブに綿棒を挿入しておく。

\section{4. 考案}

成人に比べ小児の上気道は狭く，頭蓋の発育 とともに増大するが，10歳位まではアデノイド や口蓋扁桃などのリンパ組織も肥大傾向にある ため，様々な原因で上気道の閉塞を来たしやす ( ${ }^{3,4}$ 。特に, 小顎症を伴う Pierre-Robin 症候群 や，舌根の落ち込みやすい重度心身障害児など で顕著である。鼻咽頭チューブはこれらの小児 に有効であると報告されているが1,2)，自験例で は, 上記の他に軟骨異栄養症による上気道閉塞, 先天性鼻道狭窄, 精神発達遅滞児の扁桃肥大な ぞ，様々な疾患にも全て有効であった。上気道 閉塞の治療は，鼻咽頭チューブが極めて有効で あり，体位のみで改善しない場合にはまず試み るべきである。自験例で無効であった 2 例は， それぞれ中枢性無呼吸, 喉頭気管気管支軟化症 を合併しており，単なる上気道狭窄だけの症状 を示すものではなかった。すなわち，鼻咽頭チ ューブが無効である場合は中枢神経系や下気道 の検索を進めるとともに，気管切開なども考慮
する必要がある。

文献上は鼻粘膜損傷, 分泌物の増加, 唾液の 気管内への䛊嚥, 喉頭の損傷, チューブの誤嚥5) などの報告があるが，我々の症例では重篤な合 併症は認めなかった。適切なチューブの選択と 管理でこれらの合併症は予防が可能であると考 えられる。今回の検討から，チューブの内径は, 年齢や体重ではなく原疾患に依存し，チューブ の深さは体重と正の相関を示すことがわかった が，挿入後は必ず頸部側面レントゲン写真かフ アイバースコピーでその位置を確認する必要が ある。チューブは Portex 気管内チューブを用 いたが，粘膜を損傷しやすい患児にはわずかに 外径が細く柔らかいトラキロン気管内チューブ を試してみるとよいであろう。

使用期間は 5 力月から 4 年 8 力月で平均 2 年 4 力月であった。先天性鼻道狭窄や小顎症では 身体の発育に伴い比較的短期に中止できている が，軟骨異栄養症や，精神発達遅滞を伴う閉塞 性睡眠時無呼吸や扁桃肥大では長期の鼻咽頭千 ューブ管理が必要となる。

\section{5.まと め}

鼻咽頭チューブは様々な原因の上気道閉塞に 有効であった。長期にわたって安全に，家庭で も簡便に管理ができ，気管切開に比し生活の制 約も少ないので，患児の quality of life の向上 にもつながると考える。

\section{参考文献}

1) Benjmin, B., Walker, P. : Management of airway obstruction in the Pierre Robin sequence. Int J Pediatr Otolaryngol 22 : 2937, 1991.

2 ）松井 潔，鈴木文晴，黑川 徹・他：重症心身 障害児の摄食機能に関する考察一総合的評価の 試み一。脳と発達 24:419-425, 1992.

3 ) Smith, R.M., Gonzalez, C. : The relationship between nasal obstruction and craniofacial growth. Pediatr Clin North Am 36 (6) : 14231434, 1989.

4) Drake, A.F., Davis, J.U., Warren, D.W. : Nasal airway size in cleft and nonclefo children. Larygoscope. 103: 915-917, 1993.

5 ) Milam, M.G., Miller, K.S. : Aspirtion of artificial nasopharyngeal airway. Chest 93(1) : 222-223, 1988. 